\title{
Impact of Social Media on the Development of New Products, Marketing and Customer Relationship Management in Kosovo
}

\author{
Rrezarta Gashi ${ }^{1 *}$, Hana Gashi Ahmeti ${ }^{2}$ \\ ${ }^{I}$ Faculty of Economics, AAB College, Prishtina, Kosovo \\ ${ }^{2}$ Faculty of Economics and Business, South East European University, Tetovo, North Macedonia
}

\begin{abstract}
The main objective of this paper is to highlight the importance of social media in the development of enterprises, and in particular the development of new products, and highlight the role of social media in customer relations, where the development of a new product is one of the most important elements for an enterprise. For the realization of this paper, a special questionnaire was used, where its structure was divided into three parts, where in the first part are presented the demographic questions, in the second part are the questions related to the use of social media, as and the third part includes questions related to the productivity of products and the enterprise in general. Participants in this paper were 350 companies. The paper results are presented through descriptive analysis, correlation analysis, and regression. Based on the results of this paper, we can say that Kosovar companies through social media establish relationships with their customers and keep them informed, which also greatly influences the development of new products, as well as organizational performance. Also what is noticed in this paper is the enterprises have managed to improve the quality of products through the study of customer feedback. The results also show that the use of social media to create relationships with customers and inform them, statistically affect the organizational performance and product success of Kosovo enterprises. The results also show that social media have an impact on organizational performance, the success of the company, close customer relationships, and timely information.
\end{abstract}

\section{Keywords:}

Social Media;

New Products;

Development;

Organizational Performance;

Costumer.

\section{Article History:}

$\begin{array}{llll}\text { Received: } & 17 & \text { January } & 2021 \\ \text { Revised: } & 08 & \text { March } & 2021 \\ \text { Accepted: } & 14 & \text { March } & 2021 \\ \text { Published: } & 01 & \text { April } & 2021\end{array}$

\section{1- Introduction}

In recent years, social media platforms have played a crucial role in business. This is due to the fact that the majority of users are daily social media users and this creates the opportunity for the company to be closer to its customers considering that each of us is a potential consumer for any company that is present in social media. Besides their importance in developing new products, social media also play a vital role in maintaining current products as well by keeping them frequently informed and exposed to these products. Today, Facebook and Instagram are two of the most used social media sites for the marketing of products. Through the use of various online applications, nowadays people are able to exchange numerous information and experience with other users in social media [1].

The advantage of using social networks is that exposing products online reflects in a higher number of customers, from potential customers to actual customers. In addition to this, social media platforms are essential in a business due to the fact that consumers are more easily and quickly informed about the characteristics of a product in a shorter period of time. According to Jansen et al. [2], even gossip in social media regarding certain products could lead to the

*CONTACT: Rrezartag@gmail.com

DOI: http://dx.doi.org/10.28991/esj-2021-01263

(C) 2021 by the authors. Licensee ESJ, Italy. This is an open access article under the terms and conditions of the Creative Commons Attribution (CC-BY) license (https://creativecommons.org/licenses/by/4.0/). 
decision-making of customers. Furthermore, their impact in making decisions in buying develops a certain product, whether that is an existent or a new product in the operating market. In addition to this, businesses can obtain more information about their customers, their perceptions, and their opinions regarding their competitors through social media. Every opinion from customers is crucial for the company solely for the fact that the company will be one step ahead in comparison to its competitors after making necessary changes in their business operations.

Companies in Kosovo have already created huge opportunities for the development of their products in order for them to be as close to the customers as possible, and, at the same time, they have managed to perform most effectively, have accepted others' feedbacks, and have successfully managed to display their tremendous success to the public. On the other hand, by using social media platforms, businesses are able to measure the impact they have through them and also can review the success their products achieve. Therefore I have chosen to research this topic which is current in our country, and as a country, we are in transition, therefore, this paper may serve as a direct reflection of the impact social media has on the success of Kosovo companies.

\section{2- Literature Review}

The development of a new product begins when the company finds and develops an idea about a new product [3]. Many companies see their success in the presentation of new products; however, their supervision should be much higher considering that the presentation can prove to be dangerous because many new products can lead to failure after its launch [4]. Therefore, the development of new products should go through several processes: generating ideas, reviewing these ideas, market evaluation of the idea, the product development, testing through marketing, and the commercialization process [5]. In a research conducted by Cooper [6], it is concluded that the main attributes that make the difference between new and successful products with unsuccessful ones are: the peculiarity or uniqueness of the product, sufficient information from the market, the dynamics of competitiveness in the market, market potential for product launch, marketing strategies, product price, novelties from companies, and the investment framework of the company. Besides this, a crucial part that plays in the success of new products is their quality. The figure below consists of the attributes a product development process should have in order to be successful [7]:

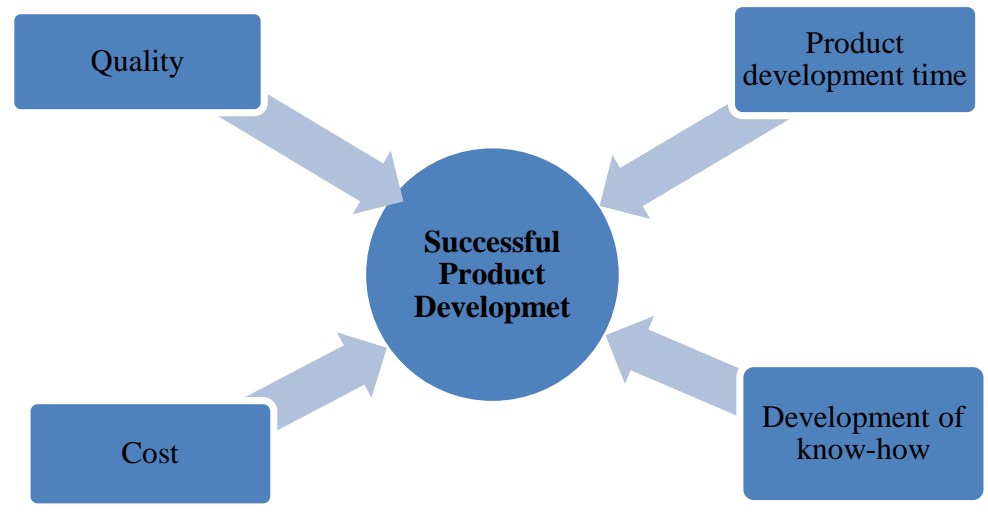

Figure 1. Successful of product development.

Considering the dynamic market in which companies today operate, the development of new products and innovation is considered as vital factors within a company. Therefore, in order for companies to be successful in their market, they should constantly innovate in their operations and products such as providing new ideas in their products to the customers [8]. Also, Cooper alludes that besides technology strategies, successful companies produce innovative products. Both these components are led by the management team of the business who have a clear strategic vision [9]. While launching new products in the market they may face various challenges such as conditioned future, previous experience from customers, and user control, and their active search [10]. This is also one of the main reasons why new products should be prioritized since customers will be able to share their experience with the product with other potential customers.

In recent years, social media platforms such as Facebook, Instagram, LinkedIn, etc., have enabled users to spread information at a rapid pace. Many applications of social media have affected businesses in making changes in various processes, such as new product development, marketing processes, services to customers, sales, etc. [11]. According to research conducted by Baum et al. [1], many companies in the retail sales and manufacturing sector apply social media campaigns in order to support the presentation of new products. Furthermore, other authors such as Nattamai et al. [12] confirm that social media sites have an incredibly important and active role in spreading information regarding the quality of products. Therefore, companies that are competing in various markets, whether they are international or local, must obtain an information technology infrastructure by including at least some of its main elements [13]. In recent years, almost all companies are using social media sites to post online their products' quality and their characteristics. Contrary to the past, social media marketing now allows companies a two-way communication with 
customers directly. Companies, through social media accounts, will be able to gain their customers' trust [14]. In this regard, promoting new products through social media and developing new groups is done at quite low costs. For this reason, enterprises prefer to use social media to reach out to their clients [15]. Tang et al. [16] assert that a benefit a company gains in social media participation is social communication, which is an extremely powerful marketing tool in building a brand's reputation and attracting new customers. In the paper of Wade [17], cited by Huotari et al. [18] it is said that what makes social media marketing more beneficial for a company than traditional marketing is that social media platforms are an interactive marketing tool that allows the audience to directly communicate with the companies and those companies are then able to engage with the customers. Whereas in traditional marketing, the audience is passive and, consequently, the communication between customers and companies is insufficient. Also, the authors Nadda et al. [19] assert that social media marketing is different from the traditional one because social media platform are open and available everywhere and at all times which gives the businesses an extraordinarily great opportunity to communicate with various communities or to even build relations with the targeted audience.

Currently, social media marketing is exceptionally necessary because it creates a clear reflection of the company to the customer and is able to detect their perceptions regarding a company's products or services. Through social media, the company secures data regarding their competitors by getting a clear picture and by also creating new ideas for their products [20]. According to the empirical study of Kenly and Poston [21], over half of the companies included in the research use social media in order to present their products' characteristics to the public, for a quicker presentation in the market, and also register lower costs in the product development. Also, according to the empirical research conducted by Drahošová and Balco [22], citing the advantages of social media to be: communication and information exchange, data exchange, teamwork and working from home, easier services, whereas Nadaraja and Yazdanifard (2013) [23] pointed to the main disadvantages of social media: intensive time spent in using them, violating copyrights, lack of trust, privacy and lack of security for data, the content of users' data, and negative reactions.

During the new product development stage through social media, companies will face various challenges and gain numerous benefits. Nadda et al. [19] suggested that the benefits of social media are: fast information collection, necessary information that can be collected through these platforms, and low operational or functional costs, whereas the main challenges that companies face are: hidden customers' needs, the lack of an effective evaluation tool, the difficulty of managing large amounts of information and lacking absorbing qualities. Recently, businesses are also using social media in various activities such as market research, targeting customers, relation management, offering services, and product promotion and sales [24].Moreover, the product development process is highly critical in organizational performance since the products are the basis of mixed marketing in each enterprise where numerous elements of the product are supported [25].

Looking at the changing climate of doing business, they are also changing its rules. In recent years, the promotion of new products is being done through social networks, where at the same time these are enabling companies' greater cooperation with customers [26]. Seeing the competitive environment in this dynamic period, the approach to the development of new products is operating in another form, whereas the easiest form to access the market is already social media [27]. It is necessary to understand the needs and requirements of consumers, not only for new items but also for existing ones. Social media is one of the main factors that is increasing the cooperation between consumers and companies, wherein this way the fulfilment of their demands and needs is becoming easier [28]. With the use of social media, many companies are already closely monitoring the performance of the market and the collection of information in a faster period of time [29]. According to the Cheng and Krumwiede [30] study, social media also identifies market trends, including the knowledge of suppliers. Also through social media increases the performance not only of existing products but also of new products.

\section{3- Research Methodology}

This research is quantitative research and its purpose is to directly measure the impact of social media usage in successful product development and the development of the company in general. The research was conducted in Kosovo with micro, small, and large companies, whereas the questionnaire was physically sent to each company and was filled in by the companies' managers or owners. The research instrument in this study is the questionnaire which consists of closed-ended questions. The first part contains demographic questions (gender, age, education level, the company's sector, and type), whereas the second part includes questions regarding social media usage (marketing, the role of media in relations and services to the customers, and their role in informing customers in a timely manner), and lastly, the third part consists questions regarding the productivity of the company and its products (information adjustment, time, cost reduction, satisfaction, and innovation). All the data have been processed through Excel and SPSS.

Regarding the sample, it is worth mentioning that the companies were randomly selected whereas the number of the companies included in the study was 369, all of them located in Kosovo. The number was determined based on the data published by the Kosovo Statistics Agency (KSA) in 2018 [31]. From the total number, 16 companies have not submitted their response, whereas 350 questionnaires are valid. 


$$
N=9223 ; e=5 \%: \text { Confidence level }=95 \%, z \text { score }=1.96 ; \text { Samplesize } \frac{\frac{z 2 x p(1-p)}{e^{2}}}{1+\left(\frac{z 2 x p(1-p)}{e 2 N}\right)}
$$

Table 1. Companies in Kosovo (Kosovo Agency of Statistics Report 2018 [31]

\begin{tabular}{cccc}
\hline Classification by size & Number of employees & Number of enterprises & Percentage of Total \% \\
\hline Micro & $2-9$ & 9.123 & 98.9 \\
Small & $40-49$ & 90 & 1.0 \\
Large & $50-259$ & 9 & 0.1 \\
Total & & 9.223 & 100 \\
\hline
\end{tabular}

\section{The research questions in this study are:}

What are the impact of social media use on organizational performance and the success of new products in companies in Kosovo?

How reliant is a company's organizational performance on establishing customer relations and informing customers in time?

\section{The research hypotheses are:}

H1: Social media usage in building relations and providing new services for customers as well as informing them in a timely manner has a statistically positive effect on the organizational performance of companies

H2: Social media usage in marketing, and in establishing positive customer relations as well as rapidly informing customers regarding their products, has a tremendous impact in increasing the organizational performance of a company, whether this is in data and time adjustment, cost reduction, satisfaction, and innovation of companies in Kosovo

H3: Organizational performance and the success of new products of companies rely on social media usage and the establishment of customer relations as well as informing them in a timely manner

H4: Organizational performance and the success of new products of companies rely on social media usage and the establishment of customer relations as well as informing them in a timely manner.

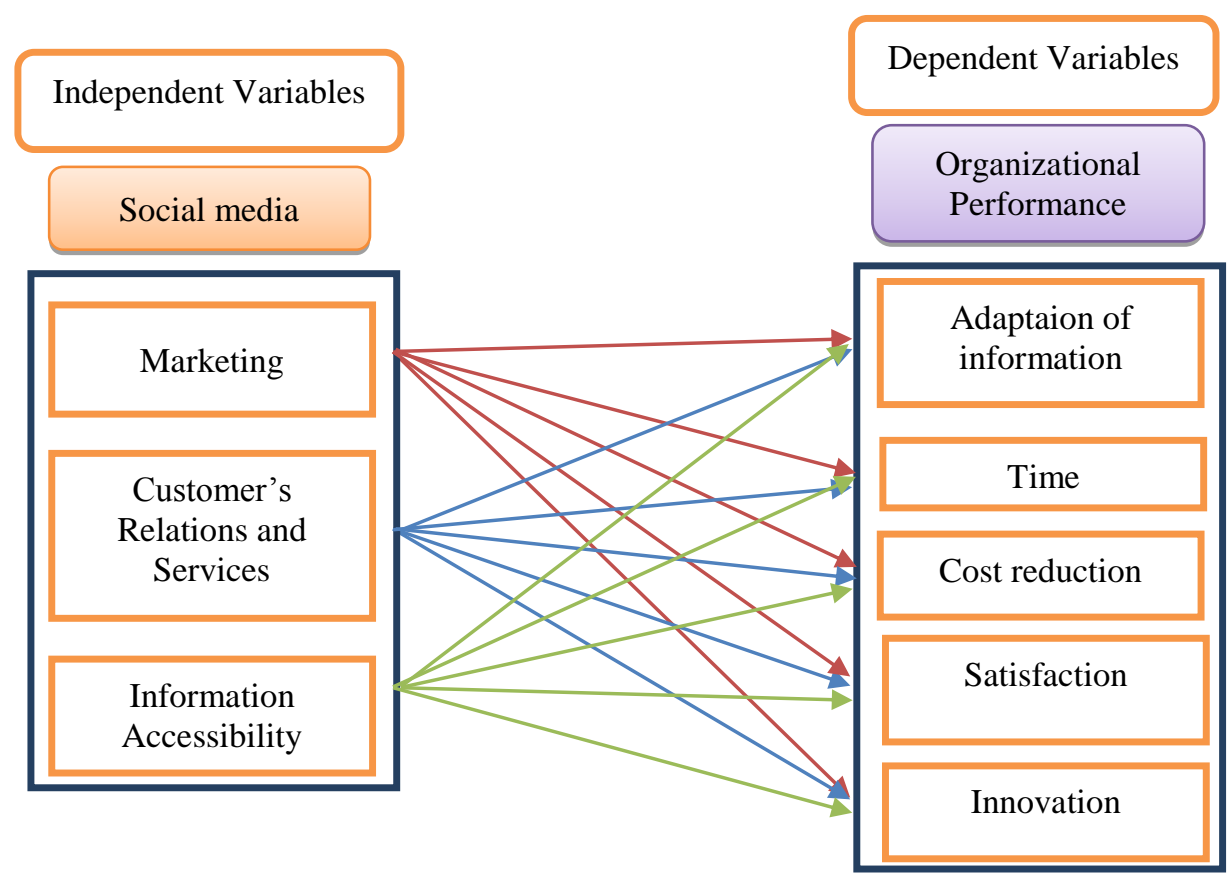

Figure 2. Logical research concept and model.

For this research is used the linear regression model for the confirmation of hypotheses by interconnecting social media as a branding tool and innovation of new products of companies as independent and dependent variables. The model's testing will be conducted according to the following formula:

$\mathrm{Yi}, \mathrm{t}=\beta 0+\beta 1$ Marketingi, $\mathrm{t}+\beta 2$ CustomRSi, $\mathrm{t}+\beta 3$ InformationAccesibilityi, $\mathrm{t}+\square \mathrm{i}, \mathrm{t}$

$\mathrm{Y}$ represents the profit and the performance growth of the company and the new product, RAP is a rapid 
adjustment, TIM is the market time, COR is the cost reduction, SAT satisfaction with marketing in social media platforms and INC is innovation as dependent variables whereas independent variables are marketing through social media, customer relations and services, information, and $\square$ - error term.

$$
\begin{aligned}
& \text { RAPi, }=\beta 0+\beta 1 \text { Marketingi, } \mathrm{t}+\beta 2 \text { CustomRSi, } \mathrm{t}+\beta 3 \text { InformationAccesibilityi, } \mathrm{t}+\square \mathrm{i}, \mathrm{t} \\
& \text { TIMi, } \mathrm{t}=\beta 0+\beta 1 \text { Marketingi, } \mathrm{t}+\beta 2 \text { CustomRSi, } \mathrm{t}+\beta 3 \text { InformationAccesibilityi, } \mathrm{t}+\square \mathrm{i}, \mathrm{t} \\
& \mathrm{CORi}, \mathrm{t}=\beta 0+\beta 1 \text { Marketingi, } \mathrm{t}+\beta 2 \text { CustomRSi, } \mathrm{t}+\beta 3 \text { InformationAccesibilityi, } \mathrm{t}+\square \mathrm{i}, \mathrm{t} \\
& \mathrm{SATi}, \mathrm{t}=\beta 0+\beta 1 \text { Marketingi, } \mathrm{t}+\beta 2 \text { CustomRSi, } \mathrm{t}+\beta 3 \text { InformationAccesibilityi, } \mathrm{t}+\square \mathrm{i}, \mathrm{t} \\
& \mathrm{INVi}, \mathrm{t}=\beta 0+\beta 1 \text { Marketingi, } \mathrm{t}+\beta 2 \text { CustomRSi, } \mathrm{t}+\beta 3 \text { InformationAccesibilityi, } \mathrm{t}+\square \mathrm{i}, \mathrm{t}
\end{aligned}
$$

For the realization of the econometric model, have used the OLS econometric model whereas the data processing has been done through SPSS. Below you may find the group of variables and their understanding.

The testing of the research model will be done by the below mentioned formula:

$$
\mathrm{Y}_{\mathrm{i}, \mathrm{t}}=\beta_{0}+\beta_{1} \mathrm{GDPPC}_{\mathrm{i}, \mathrm{t}}+\beta_{2} \mathrm{EMSII}_{\mathrm{i}, \mathrm{t}}+\beta_{3} \mathrm{EMSSI}_{\mathrm{i}, \mathrm{t}}+\beta_{4} \mathrm{LBPP}_{\mathrm{i}, \mathrm{t}}+\square_{\mathrm{i}, \mathrm{t}}
$$

Y represents the total number of employees, GDPPC the gross domestic product, EMSI the employees in the industry sector, EMSS the employees in the services sector, and LBPP labour productivity presented in the number of hours working and $\square$ presents the term 'error', which tells how certain can be about the formula. In this case, the employment rate (EPRT) is presented as a dependent variable, whereas independent variables are the gross domestic products (GDPPC), employees in the industry sector (EMSI), employees in the services sector (EMSS), and labour productivity (LBPP), specifically variables.

HO. There is a statistically significant positive impact in generation in new jobs in Kosovo from small and medium enterprises (SMEs)

Sub-hypotheses:

H01. Number of employees or generating new jobs depends on GDPPC;

H02. Number of employees or generating new jobs from SMEs in Kosovo depends on the labour productivity;

H03. Number of employees or generating new jobs from SMEs in Kosovo depends on the total number of employees from the total number of employees in the companies in the industry sector;

H04. Number of employees or generating new jobs from SMEs in Kosovo depends on the total number of employees in companies in the services sector.

\section{4- Research Analyzes}

350 businesses in Kosovo were part of this paper, whereas the questionnaire was filled by the managers of these businesses, $223(63.72 \%)$ were male and 127 female $(36.28 \%)$. 171 respondents $(48.9 \%)$ were of the group age $18-25$ years, 96 respondents $(27.4 \%)$ were of the group age $26-35$ years, 59 respondents $(16.9 \%)$ were of the group age $36-45$ years, 23 respondents $(6.6 \%)$ were of the group age $46-55$ years, and 1 respondent $(0.3 \%)$ was 55 years old. Regarding their education background, 6 respondents $(1.7 \%)$ were with medium qualification, 245 respondents $(70 \%)$ were with undergraduate qualification, and 99 respondents (28.3\%) were with superior qualification.

Regarding the field of the company, 226 of them were individual companies or $64.6 \%, 7$ companies $(2 \%)$ had general partnerships, 37 companies (10.6\%) were limited liability companies, 16 companies (4.6\%) were joint-stock companies, $25(7.1 \%)$ were foreign companies, 7 (2\%) were social companies, $22(6.3 \%)$ were public companies and $10(2.9 \%)$ were agricultural cooperatives. From the total number, 41 (11.7\%) were micro businesses, $190(54.3 \%)$ small businesses, and 119 (34\%) were large businesses.

Table 2. Descriptive statistics of respondents.

\begin{tabular}{ccc}
\hline Gender & $\mathbf{N}$ & $\boldsymbol{\%}$ \\
\hline Male & 223 & $63.72 \%$ \\
Female & 127 & $36.28 \%$ \\
\hline Age group & $\mathbf{N}$ & $\boldsymbol{\%}$ \\
\hline 18-25 years & 171 & $48.9 \%$ \\
26-35 years & 96 & $27.4 \%$ \\
36-45 years & 59 & $16.9 \%$ \\
46-55 years & 23 & $6.6 \%$ \\
Over 55 years & 1 & $0.3 \%$
\end{tabular}




\begin{tabular}{ccc}
\hline Level of education: & $\mathbf{N}$ & $\%$ \\
\hline Secondary school & 6 & $1.7 \%$ \\
Bachelor & 245 & $70.0 \%$ \\
Master or Phd & 99 & $28.3 \%$ \\
\hline Your company is: & $\mathbf{N}$ & $\%$ \\
\hline Individual business & 226 & $64.6 \%$ \\
Overall Partnership & 7 & $2.0 \%$ \\
Limited Liability Company (L.L.C) & 37 & $10.6 \%$ \\
Joint Stock Company (J.S.C) & 16 & $4.6 \%$ \\
Foreign Company & 25 & $7.1 \%$ \\
Socially owned company & 7 & $2.0 \%$ \\
Public company & 22 & $6.3 \%$ \\
Farm cooperatives & 10 & $2.9 \%$ \\
\hline Your company is: & $\mathbf{N}$ & $\%$ \\
\hline Micro company & 41 & $11.7 \%$ \\
Small company & 190 & $54.3 \%$ \\
Big company & 119 & $34.0 \%$ \\
\hline
\end{tabular}

The following results represent the opinion of the managers of these companies regarding the application of social media and their impact in the company's performance. This part includes the presentation of the managers' opinions regarding the utilization of social media in marketing and thereby the minimum, maximum, and average value, and the standard deviation are presented. It is noteworthy to mention that the majority of managers have evaluated highly the use of social media, while on the other hand, they have expressed a lower level of satisfaction reagrding the use of various languages in promoting the products of the company in social media platforms. In this context we understand that this is a drawback for us and that companies need to pay great importance to social media in order for them to publish or even do marketing in other languages and not just in their native language.

Table 3. Descriptive Statistics.

\begin{tabular}{|c|c|c|c|c|c|}
\hline Questions & $\mathbf{N}$ & Min. & Max. & Mean & $\begin{array}{c}\text { Std. } \\
\text { Deviation }\end{array}$ \\
\hline The company uses social media to advertise their products & 350 & 1 & 5 & 4.02 & 1.262 \\
\hline The company is seeking through the means of social media to promote its brand & 350 & 1 & 5 & 4.07 & 1.151 \\
\hline $\begin{array}{l}\text { The company operates through the means of social media in the evaluation of its performance marketing } \\
\text { by getting feedback from (Likes, shares and follow-up of Instagram, Facebook, and Twitter) }\end{array}$ & 350 & 1 & 5 & 4.04 & 1.160 \\
\hline The company uses different languages in marketing through social media & 350 & 1 & 5 & 3.98 & 1.196 \\
\hline The company kept pace with trends and new social media sites to get a competitive advantage & 350 & 1 & 5 & 4.16 & 1.030 \\
\hline The company systematically collected customer feedback on social media sites & 350 & 1 & 5 & 4.07 & 1.141 \\
\hline $\begin{array}{l}\text { The company develops its relationship with customers through constant communication with them } \\
\text { through the means of social media }\end{array}$ & 350 & 1 & 5 & 4.16 & 0.989 \\
\hline The company operates through the means of social media in doing customer service activities & 350 & 1 & 5 & 4.05 & 1.002 \\
\hline $\begin{array}{l}\text { The company improved the quality of their products through the study of customer feedback through } \\
\text { social media }\end{array}$ & 350 & 1 & 5 & 4.18 & 1.124 \\
\hline $\begin{array}{l}\text { The company operates through the means of social media in the search for general information about } \\
\text { the target market }\end{array}$ & 350 & 1 & 5 & 3.96 & 1.155 \\
\hline The company uses social media to search for competitors' information & 350 & 1 & 5 & 4.14 & 1.087 \\
\hline $\begin{array}{l}\text { The company provides through the means of social media full information about the cost and the } \\
\text { expected date of delivery }\end{array}$ & 350 & 1 & 5 & 4.21 & 1.109 \\
\hline The company uses social media to provide full details of their products & 350 & 1 & 5 & 4.09 & 1.114 \\
\hline $\begin{array}{l}\text { The company is working to create and update a database to its customers through the means of social } \\
\text { media }\end{array}$ & 350 & 1 & 5 & 4.19 & 1.064 \\
\hline $\begin{array}{l}\text { The company possesses the ability to respond rapidly to changes in the work environment (internal or } \\
\text { external variables) }\end{array}$ & 350 & 1 & 5 & 4.09 & 1.156 \\
\hline $\begin{array}{l}\text { The company chooses suppliers are characterized by flexibility in responding to requests by the } \\
\text { company when needed }\end{array}$ & 350 & 1 & 5 & 4.05 & 1.044 \\
\hline $\begin{array}{l}\text { The company has expertise and capabilities in } \mathrm{R} \& \mathrm{D} \text { department able to keep pace with the rapid } \\
\text { changes in the work environment }\end{array}$ & 350 & 1 & 5 & 4.29 & 0.998 \\
\hline The company urgently needed changes in the conduct by the agent in the product characteristics & 350 & 1 & 5 & 4.01 & 1.134 \\
\hline
\end{tabular}




\begin{tabular}{|c|c|c|c|c|c|}
\hline $\begin{array}{l}\text { The company has the ability to develop existing products within a short period of time (less than six } \\
\text { months) }\end{array}$ & 350 & 1 & 5 & 4.19 & 0.957 \\
\hline The company continues to invest in advanced technology to improve their products and services & 350 & 1 & 5 & 4.11 & 1.058 \\
\hline $\begin{array}{l}\text { The company relies on feedback from customers to help determine the most appropriate time to launch } \\
\text { new products on the market }\end{array}$ & 350 & 1 & 5 & 4.18 & 1.014 \\
\hline The company works to enter into new markets and regions to help spread globally & 350 & 1 & 5 & 4.18 & 0.942 \\
\hline $\begin{array}{l}\text { The company used a variety of marketing techniques to help increase the awareness and knowledge of } \\
\text { customers for new products on the market }\end{array}$ & 350 & 1 & 5 & 4.10 & 1.041 \\
\hline The company pursues a policy of reducing costs while maintaining & 350 & 1 & 5 & 4.18 & 1.135 \\
\hline The company plans to reduce the maintenance costs of machinery and equipment & 350 & 1 & 5 & 4.14 & 1.160 \\
\hline The company plans to reduce transportation costs & 350 & 1 & 5 & 4.27 & 0.987 \\
\hline The company is seeking to reduce the wasteful use of resources (electricity, water, raw materials) & 350 & 1 & 5 & 4.06 & 1.204 \\
\hline $\begin{array}{l}\text { The company is working on economies of scale (production in large quantities to reduce the cost per } \\
\text { piece) }\end{array}$ & 350 & 1 & 5 & 4.24 & 1.099 \\
\hline The importance of any task, no matter how small, is appreciated by higher management & 350 & 1 & 5 & 3.89 & 1.064 \\
\hline Management empowers its employees to get better results & 350 & 1 & 5 & 3.94 & 1.003 \\
\hline Employees allowed expressing their views and problems & 350 & 1 & 5 & 3.83 & 1.116 \\
\hline Staff incentives are awarded for outstanding performance regardless of the functional level & 350 & 1 & 5 & 3.83 & 1.082 \\
\hline Managers seek solutions that satisfy conflict parties & 350 & 1 & 5 & 3.91 & 0.926 \\
\hline Management makes sure that responsibilities are clear to all employees & 350 & 1 & 5 & 4.00 & 1.042 \\
\hline The company characterized by innovation in production methods & 350 & 1 & 5 & 4.14 & 0.971 \\
\hline The company applied new innovative methods in advertising their products and services & 350 & 1 & 5 & 4.19 & 0.899 \\
\hline The company is always looking for new innovative ways to deliver their products ways & 350 & 1 & 5 & 4.07 & 1.041 \\
\hline $\begin{array}{l}\text { The company decided to change the properties of the shape of the product and its quality on the basis of } \\
\text { a new innovative idea }\end{array}$ & 350 & 1 & 5 & 4.17 & 1.023 \\
\hline The company encourages new innovative ideas & 350 & 1 & 5 & 4.17 & 0.993 \\
\hline Valid N (list wise) & 350 & & & & \\
\hline
\end{tabular}

From the results we notice that managers were satisfied with the role of media in customer relations and services, for which in every occasion the study has found that we have a high level of satisfaction and a low level of standard deviation which implies that media have a relatively similar impact. Regarding the role of social media in informing customers at a quicker pace, we notice that companies are still facing difficulties in effectively utilizing social media platforms in order to reach the targeted market, even though in several occasions there is a moderate level of satisfaction and low level of standard deviation. Managers highly evaluate the information adjustment, and it can be noted that regarding the ability to develop current and new products within a short period of time the managers say that this is evident and they are registering success. In line with our findings is a study from Elena 2016 [32] which have used questionnaires to analyze the necessity of transition from traditional CRM to social CRM thus emphasizes examples of how companies can benefit from the use of social media, growing sales and profitability, creating advertisements, acquiring new customers, retaining them and make them loyal and conludes that companies are almost being obliged to implement SCRM in their marketing strategies, due to the fact that it is a powerful marketing tool which provides useful client experience insights, acknowledging their dissatisfactions, as well as receiving their positive feedbacks and recommendations. Companies should adapt to the rise of this new trend - social media. Regarding the role of social media in informing customers at a quicker pace, we notice that companies are still facing difficulties in effectively utilizing social media platforms in order to reach the targeted market, even though in several occasions there is a moderate level of satisfaction and low level of standard deviation. Managers highly evaluate the information adjustment, and it can be noted that regarding the ability to develop current and new products within a short period of time the managers say that this is evident and they are registering success. Listening to what people are saying on social media helps you know their needs, frustrations, fears, goals, and desires, helping you understand what makes them engage with you [33]. On the other hand, they consider other factors related to information adjustment in social media. When considering time as an essential factor in the performance of companies, it can be noted that this is considered more than in other occasions, i.e. by reducing the time spent they have a higher representation of their companies to their customers. In other occasions there are several other factors that are significant such as investment, customers' reactions and access to markets. It is important to consider the future of social media in the context of consumer behaviour and marketing, since social media has become a vital marketing and communications channel for businesses, organizations and institutions alike [34].

Managers unanimously agree that social media impact the cost reduction and this also reflects in the quality of products, machinery and equipment maintenance, which is then noted in lower transportation costs, lower insignificant 
use of sources such as electricity and water, and also has a direct effect in the company by making it work more and partly reducing costs. The utilization of social media platforms also has a tremendous impact in the satisfaction of managers within a company, which is shown in better results, the company itself has the chance to receive recommendations in solving their problems, and also this impacts the stimulation of the staff and general aspects. Whereas taking into account the impact of social media usage in innovation, the results show that all managers' responses were positive due to the fact that social media have had impact in increasing novelties within the companies and have established new methods of production. Besides these, these platforms have proven to be quite effective in advertising products and their services, they have encouraged new ideas and have supported employees in developing their ideas. Another study from Kumar et al. (2017) enables managers to not only better understand the synergistic effects of social media marketing and traditional marketing, but also the time-varying effectiveness of their marketing efforts with TVEM approach for better resource allocation [35].

The reliability test is conducted in order to measure the validity of assertions and the continuation of the analyses and the confirmation of hypotheses. The following results show that Alpha Cronbach's at Social Media for Marketing (0.941), the role of social media in customer relations (0.914), followed by the group of assertions "the role of media in rapidly informing customers" (0.937), information adaptation (0.903), time (0.913), cost reduction (0.909), customer satisfaction (0.917), innovation (0.930), and the general average value of Cronbach's Alpha is (0.920). This is a high level of reliability and we assert that the assertions are reliable and valid in order to continue with further analyses.

Table 4. Value of Alpha Cronbach's.

\begin{tabular}{cc}
\hline Variable & Alpha Cronbach's \\
\hline Social media for marketing & 0.941 \\
The role of social media in customer relationships and services & 0.914 \\
The role of social media in rapidly informing consumers & 0.937 \\
Adaptation of information & 0.903 \\
Time & 0.913 \\
Cost reduction & 0.909 \\
Satisfaction & 0.917 \\
Innovation & 0.930 \\
Average Level: & 0.920 \\
\hline
\end{tabular}

The normality test was conducted through Kolmogorov_smirno and Shapiro-Wilk, and in both cases the p value or the significant is 0.000 which shows that our data have an abnormal or assymetrical dispersal, and in this case the assymetrical tests will be utilized in order to confirm the hypotheses.

Table 5. Test of normality

\begin{tabular}{|c|c|c|c|c|c|c|}
\hline \multirow{2}{*}{ Variable } & \multicolumn{3}{|c|}{ Kolmogorov-Smirnov ${ }^{a}$} & \multicolumn{3}{|c|}{ Shapiro-Wilk } \\
\hline & Statistic & df & Sig. & Statistic & df & Sig. \\
\hline Social media for marketing & 0.183 & 350 & 0.000 & 0.840 & 350 & 0.000 \\
\hline The role of social media in customer relationships and services & 0.184 & 350 & 0.000 & 0.842 & 350 & 0.000 \\
\hline The role of social media in rapidly informing consumers & 0.186 & 350 & 0.000 & 0.836 & 350 & 0.000 \\
\hline Adaptation of information & 0.172 & 350 & 0.000 & 0.861 & 350 & 0.000 \\
\hline Time & 0.189 & 350 & 0.000 & 0.854 & 350 & 0.000 \\
\hline Cost reduction & 0.196 & 350 & 0.000 & 0.820 & 350 & 0.000 \\
\hline Satisfaction & 0.118 & 350 & 0.000 & 0.934 & 350 & 0.000 \\
\hline Innovation & 0.176 & 350 & 0.000 & 0.864 & 350 & 0.000 \\
\hline
\end{tabular}

The correlation between the application of social media and the positive impact in adaptation of information, time, cost reduction, satisfaction, and innovation.

H1: The utilization of social media in regards to building relations with and providing services to customers has a significantly positive impact in the organizational performance of companies. The partial correlation test has been used in this analysis where the independent variables used are the role of social media in relation to customers, and the role of social media in rapidly informing customers in order to examine organizational performance as a dependent variable. 
Table 6. Analyzes of correlation

\begin{tabular}{|c|c|c|c|c|}
\hline \multicolumn{3}{|c|}{ Control Variables } & $\begin{array}{c}\text { The role of social media in customer } \\
\text { relationships and services }\end{array}$ & $\begin{array}{l}\text { The role of social media in } \\
\text { rapidly informing consumers }\end{array}$ \\
\hline \multirow{6}{*}{$\begin{array}{l}\text { Organizational } \\
\text { performance }\end{array}$} & \multirow{3}{*}{$\begin{array}{l}\text { The role of social media in } \\
\text { customer relationships and } \\
\text { services }\end{array}$} & Correlation & 1.000 & 0.709 \\
\hline & & Significance (2-tailed) & . & 0.000 \\
\hline & & $\mathrm{df}$ & 0 & 347 \\
\hline & \multirow{3}{*}{$\begin{array}{l}\text { The role of social media in } \\
\text { rapidly informing consumers }\end{array}$} & Correlation & 0.709 & 1.000 \\
\hline & & Significance (2-tailed) & 0.000 & . \\
\hline & & df & 347 & 0 \\
\hline
\end{tabular}

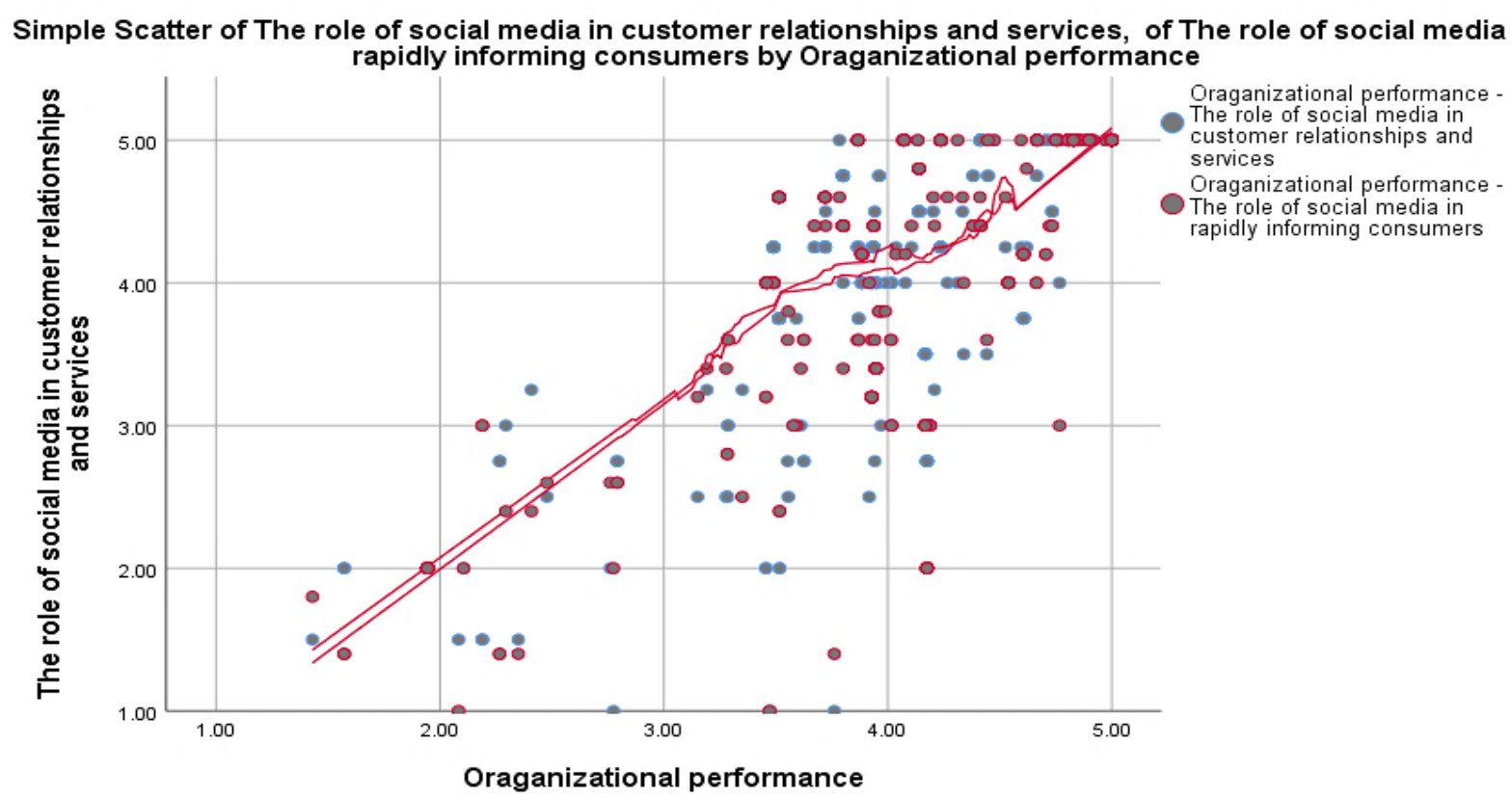

Figure 3. Simple scatter of role of social media in customer relationships and services.

H2: Using social media in marketing, in building positive relations with customers, and in rapidly informing customers, has a highly positive impact in increasing the organizational performance in the aspect of adapting information, time, cost reduction, satisfaction, and innovation in companies in Kosovo.

In the following analysis we have used the Spearman Correlation test which is used data with nonparametric measure. The purpose of the analysis is to note how high the impact of social media utilization in organizational performance is. From the results we see that that there is a high positive correlation between the use of media $($ rho $=0.767 * *, p$ value $=0.000)$ and organizational performance which is considered of $1 \%$ impact in the reliability level.

Table 7. Analyzes of correlation.

\begin{tabular}{cclcc}
\hline & & Use of social media & Organizational performance \\
\hline \multirow{4}{*}{ Use of social media } & Correlation Coefficient & 1.000 & $0.767^{* *}$ \\
& Sig. (2-tailed) & $\cdot$ & 0.000 \\
& $\mathrm{~N}$ & & 350 \\
\cline { 2 - 5 } Spearman's rho & Correlation Coefficient & & 1.000 \\
\cline { 2 - 4 } & Organizational & Sig. (2-tailed) & \\
\hline & performance & $\mathrm{N}$ & & $\cdot$ \\
\hline
\end{tabular}

**. Correlation is significant at the 0.01 level (2-tailed). 


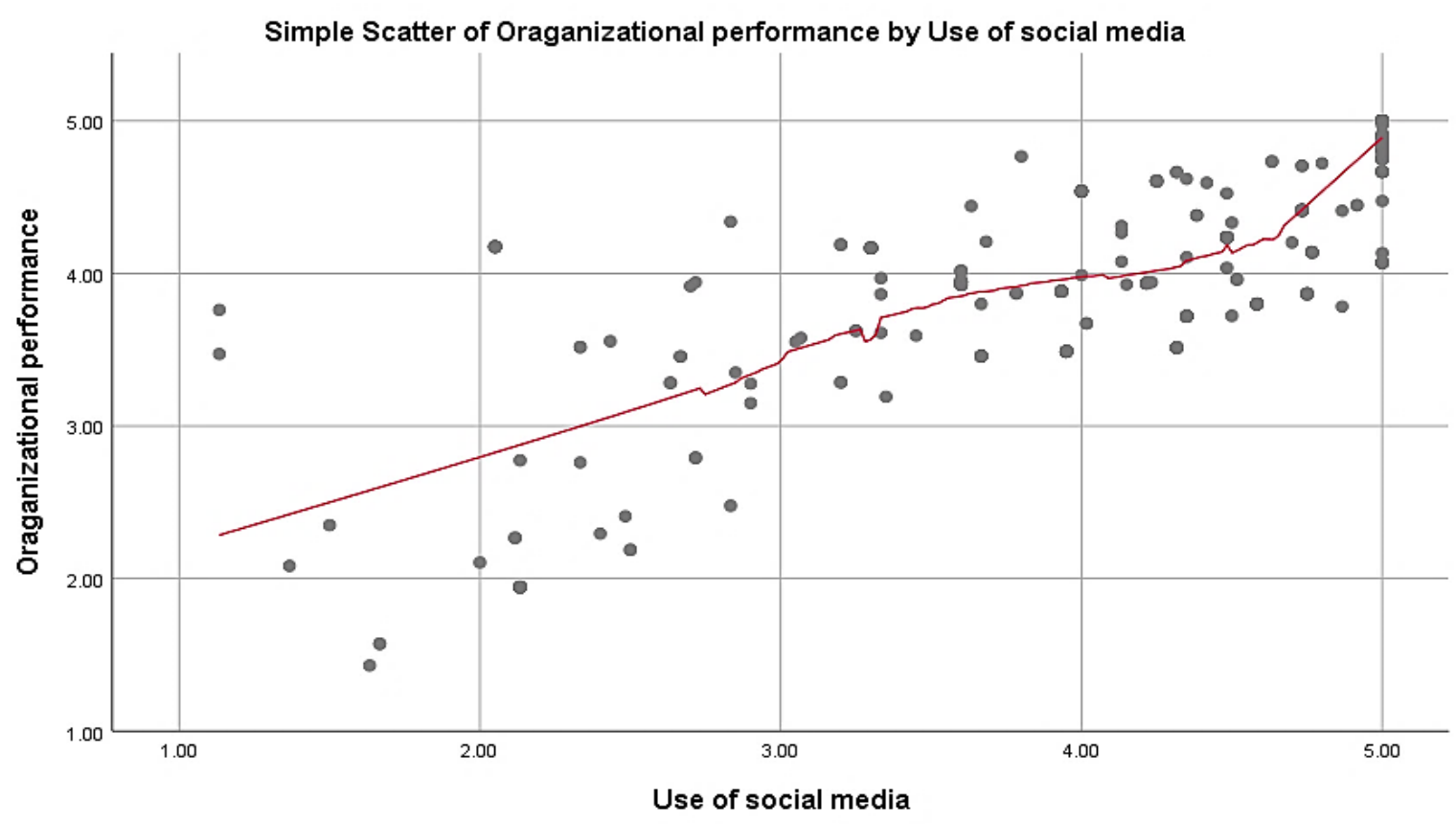

Figure 4. Simple scatter of organizational performance by use of social media.

The correlation analysis has been conducted in order to confirm the impact and dependence of the organizational performance of a company and the success of products through the use of social media.

H3: Organizational performance and the success of new products rely on the use of social media and building customer relations as well as rapidly keeping them up to date.

The results show the role of social media in building customer relations $(\mathrm{B}=0.502, \mathrm{SH}=0.053, \beta=0.633$ and $\mathrm{p}$ value $=0.000)$ and the role of social media in rapidly informing consumers $(\mathrm{B}=0.113, \mathrm{SH}=.051, \beta=0.174$ and $\mathrm{p}$ value $=0.010$ ), with high correlation rho rho $=0.793$, regression $\mathrm{R}^{2}=0.624, \Delta \mathrm{R}^{2}=0.621$, test $\mathrm{F}=287.243$ and $\mathrm{p}$ value $=0.000$. We conclude from these results that the use of social media in building customer relations and keeping customers rapidly informed impact significantly the organizational performance and the success of the products made by companies in Kosovo in $1 \%$ of the reliability level.

Table 8. Analyzes of regression.

\begin{tabular}{ccccc}
\hline \multirow{2}{*}{ Independent Variables } & \multicolumn{3}{c}{ Model -1- } \\
\cline { 2 - 5 } & B & S.H. & $\boldsymbol{\beta}$ & Sig. \\
\hline The role of social media in customer relationships and services & 0.502 & 0.053 & 0.633 & 0.000 \\
The role of social media in rapidly informing consumers & 0.133 & 0.051 & 0.174 & 0.010 \\
\hline $\mathrm{R}$ & \multicolumn{3}{c}{0.793} \\
$\mathrm{R}^{2}$ & \multicolumn{2}{c}{0.624} \\
$\Delta \mathrm{R}^{2}$ & \multicolumn{3}{c}{0.621} \\
\hline $\mathrm{F}$ & \multicolumn{3}{c}{287.243} \\
\hline ANOVA (Sig.) & \multicolumn{3}{c}{0.000} \\
Dependent variable & \multicolumn{3}{c}{ Organizational performance } \\
\hline
\end{tabular}

The regression analysis between the organizational performance and the social media utilization to build good relations with customers and keeping them informed. 


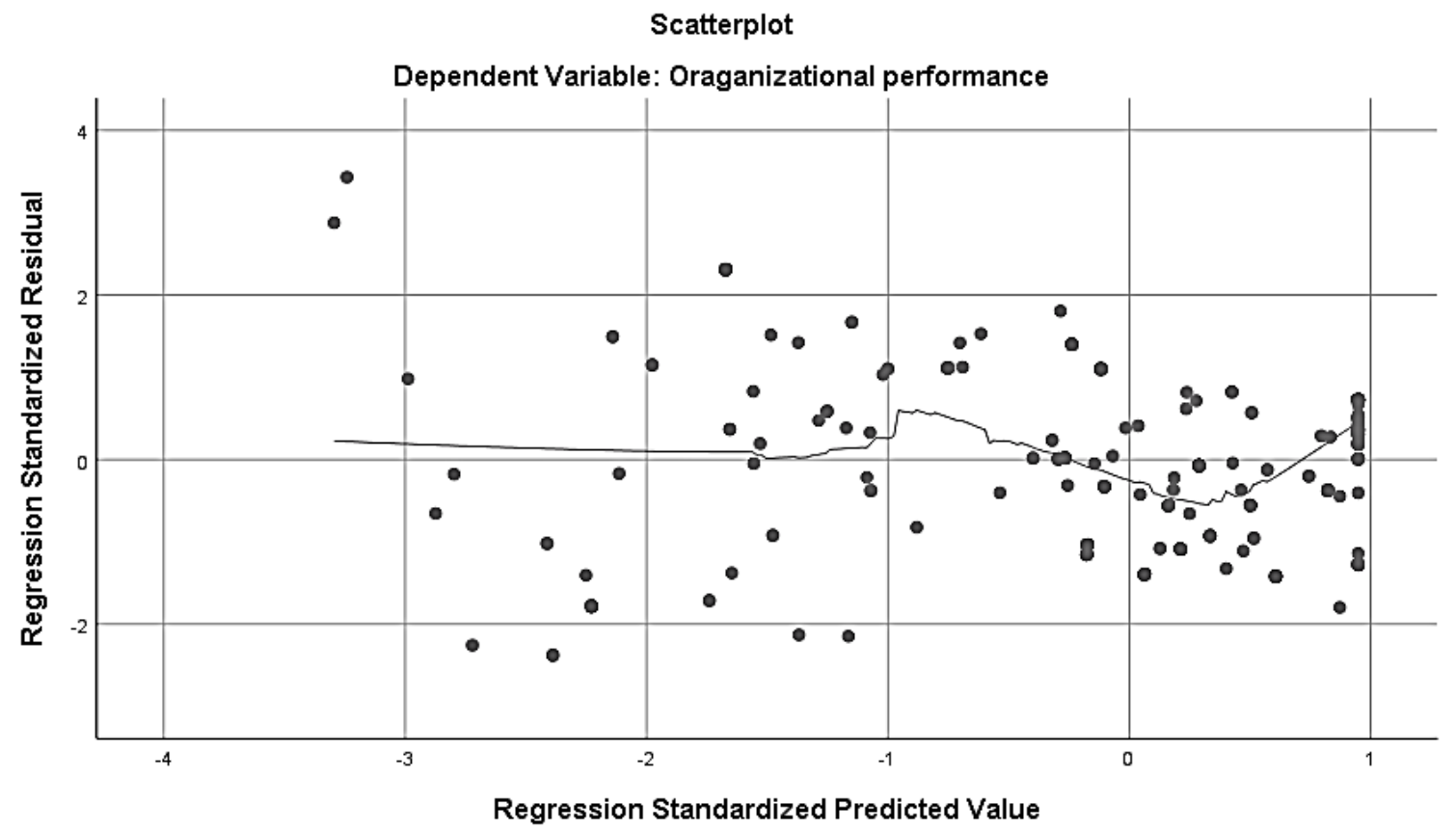

Figure 5. Simple scatter of organizational performance by use of social media.

H4: Organizational performance and the success of products of companies rely on the use of social media and the establishment of customer relations and keeping them up to date in time.

The results shown below show that there is a significant reliance, specifically at the information adaptation $(\mathrm{B}=0.897, \mathrm{SH}=0.065, \beta=0.851$ and $\mathrm{p}$ value $=0.000)$, time $(\mathrm{B}=0.325, \mathrm{SH}=0.007, \beta=-0.309$ and $\mathrm{p}$ value $=0.000)$, then at cost reduction $(\mathrm{B}=0.040, \mathrm{SH}=0.064, \beta=0.041$ and $\mathrm{p}$ value $=0.532)$, satisfaction $(\mathrm{B}=0.123, \mathrm{SH}=0.055, \beta=0.114$ and $\mathrm{p}$ value $=0.026)$ and innovation $(\mathrm{B}=0.141, \mathrm{SH}=0.061, \beta=0.129$ and $\mathrm{p}$ value $=0.021)$, correlation rho $=0.780 * *$, regression $\mathrm{R}^{2}=0.609, \Delta \mathrm{R}^{2}=0.603$, test $\mathrm{F}=107.113$ and $\mathrm{p}$ value $=0.000$, where there is no significant reliance in cost reduction whereas in the other occasions the reliance is statistically significant. Thus, this shows that the organizational performance is reliant directly on the use of social media and building customer relations and keeping them informed in time at $1 \%$ of the reliability level.

Table 9. Analyzes of regression.

\begin{tabular}{ccccc}
\hline \multirow{2}{*}{ Independent Variables } & \multicolumn{5}{c}{ Model -1- } \\
\cline { 2 - 5 } & $\mathbf{B}$ & S.H. & $\boldsymbol{\beta}$ & Sig. \\
\hline Adaptation of information & 0.897 & 0.065 & 0.851 & 0.000 \\
Time & -0.325 & 0.077 & -0.309 & 0.000 \\
Cost reduction & 0.040 & 0.064 & 0.041 & 0.532 \\
Satisfaction & 0.123 & 0.055 & 0.114 & 0.026 \\
Innovation & 0.141 & 0.061 & 0.129 & 0.021 \\
\hline $\mathrm{R}$ & \multicolumn{5}{c}{$0.780^{*} *$} \\
$\mathrm{R}^{2}$ & \multicolumn{5}{c}{0.609} \\
$\Delta \mathrm{R}^{2}$ & \multicolumn{5}{c}{0.603} \\
$\mathrm{~F}$ & \multicolumn{5}{c}{0.000} \\
\hline ANOVA (Sig.) & \multicolumn{5}{c}{ Us of social media } \\
Dependent variable
\end{tabular}

\section{6- Discussion}

In $t$ this study we find that the role of social media in informing customers at a quicker pace, is of great importance. We notice that companies are still facing difficulties in effectively utilizing social media platforms in order to reach the targeted market, even though in several occasions there is a moderate level of satisfaction and low level of standard deviationIn line with our findings there is another study from Farzana et al. [36] that used survey with a sample of 174 organisations and find out that social media usage has a very strong positive impact on organizations' performance, in terms of cost reduction, improved customer relations, and enhanced information accessibility.The 
utilization of social media platforms also has a tremendous impact in the satisfaction of managers within a company, which is shown in better results, the company itself has the chance to receive recommendations in solving their problems, and also this impacts the stimulation of the staff and general aspects. Whereas taking into account the impact of social media usage in innovation, the results show that all managers' responses were positive due to the fact that social media have had impact in increasing novelties within the companies and have established new methods of production. Also a study from Oyekunle et al. [37] using well-structured questionnaire in order to obtain data from 113 purposively sampled building materials' used partial least squares structural equation modelling technique to establish the relationship among the constructs and come in conclusion that technology has significant relationship with social media adoption, whereas social media adoption has a very strong positive impact on organisation's performance $(P<0.001)$ with respect to improved customer relations and services and enhanced information accessibility. It is worth noting considering that 3.5 billion people (about half the world's population) are on social media daily, it's not surprising that $73 \%$ of marketers agree that social media is somewhat or very effective in their business strategy[38]. The products whose development is from social media platforms are the ones that are compliant with the general strategies of product development as well as with innovation strategies [21]. Besides the development of new products, In addition in 2021, marketers can still drive quick bursts of ROI from new customers using social ads. But they also need to provide online social experiences that help build relationships and brand loyalty [39]. Kosovo companies should every article advertise through social networks, in order for their development to be greater.

\section{7- Conclusions}

This study deeply focused in the analysis of social media impact in the development of new products as well as in the organizational performance of companies in Kosovo where we see that the performance of many businesses is directly affected by the development of their products. From the results of this study we conclude that managers were satisfied with the role of media in customer relations and services, for which in every occasion the study has found that we have a high level of satisfaction which implies that media have a relatively important impact. In addition to this, in this research a conceptual model has been established being based on the theoretical aspect of the social media impact. By analysing the results from this research, we notice that in Kosovo, as in many other countries, social media platforms have a tremendous impact in the development of new products. Kosovo companies are already using social media in making sure their customers are informed as early as possible about their products as well as building relations with them. The companies in case of Kosovo are following the latest foreign trends regarding the development of their products thus the social media is crucial and the information adjustment is of great importance. Taking into consideration the trend of the globalization, it is worth noted that Kosovo companies should advertise their products using social media in order to raise their productivity and also to advertise their product in other foreign languages and not to be focused only in using their native language.

\section{8- Declarations}

\section{8-1- Author Contributions}

Conceptualization, R.G., H.G.A.; writing—original draft preparation, R.G., H.G.A.; writing—review and editing. All authors have read and agreed to the published version of the manuscript.

\section{8-1- Data Availability Statement}

The data presented in this study are available in article

\section{8-2- Funding}

The authors received no financial support for the research, authorship, and/or publication on this article.

\section{8-3- Conflicts of Interest}

The author declares that there is no conflict of interests regarding the publication of this manuscript. In addition, the ethical issues, including plagiarism, informed consent, misconduct, data fabrication and/or falsification, double publication and/or submission, and redundancies have been completely observed by the authors..

\section{9- References}

[1] Baum, Daniela, Martin Spann, Johann Füller, and Carina Thürridl. "The Impact of Social Media Campaigns on the Success of New Product Introductions." Journal of Retailing and Consumer Services 50 (September 2019): $289-297$. doi:10.1016/j.jretconser.2018.07.003.

[2] Jansen, Bernard J., Mimi Zhang, Kate Sobel, and AbdurChowdury. "Twitter Power: Tweets as Electronic Word of Mouth." Journal of the American Society for Information Science and Technology 60, no. 11 (November 2009): 2169-2188. doi:10.1002/asi.21149.

[3] Kotler, Philip, and Armstrong Gary. Principles of Marketing. Edited by 13. Pearson Education, 2012. 
[4] Hultink, Erik Jan, and Henry S. J. Robben. "Measuring New Product Success: The Difference That Time Perspective Makes." Journal of Product Innovation Management 12, no. 5 (November 1995): 392-405. doi:10.1111/1540-5885.1250392.

[5] Saren, M. A. "A Classification and Review of Models of the Intra-Firm Innovation Process.” R\&D Management 14, no. 1 (January 1984): 11-24. doi:10.1111/j.1467-9310.1984.tb00504.x.

[6] Cooper, R.G. “The Dimensions of Industrial New Product Success and Failure.” Journal of Marketing 43, no. 3 (June 1979): 93-103. doi:10.1177/002224297904300310.

[7] Mital, Anil, Anoop Desai, Anand Subramanian, and Aashi Mital. "Design Review.” Product Development:A Structured Approach to Consumer Product Development, Design, and Manufacture (2008): 71-91. doi:10.1016/b978-075068309-8.50006-6.

[8] Udegbe, Scholastica, and Maurice Udegbe. "Impact of product development and innovation on organisational performance." International Journal of Management and Sustainability (Conscientia Beam) 2, no. 12 (November 2013): 220-230.

[9] Cooper, Robert G. "Winning at new products: pathways to profitable innovation." In Proceedings Project Management Research Conference, Montreal, Canada. 2006. Available online: http://www.bobcooper.ca/images/files/articles/1/2-Winning-at-NewProducts-Pathways-to-Profitable-Innovation.pdf (accessed on 1 January 2020).

[10] Urban, Glen L., Bruce D. Weinberg, and John R. Hauser. "Premarket Forecasting of Really-New Products." Journal of Marketing 60, no. 1 (January 1996): 47-60. doi:10.1177/002224299606000105.

[11] Weinberg, Bruce, Ko de Ruyter, Chrysanthos Dellarocas, Michael Buck, and Debbie Isobel Keeling. "Destination Social Business: Exploring an Organization's Journay with Social Media, Collaborative Community and Expressive Individuality." Journal of Interactive Marketing (Elsevier) 27, no. 4 (November 2013): 299-310. doi:10.1016/j.intmar.2013.09.006.

[12] Nattamai Kannan, Karthik Babu, Yu Hu, and Sridhar Narasimhan. "Social Media, Flash Sales, and the Maker Movement: An Empirical Analysis.” SSRN Electronic Journal (2016). doi:10.2139/ssrn.2829855.

[13] Domniku, Sokol. "Roli dhe ndikimi i teknologjise informatike ne prodhimin dhe shfrytezimin e informatave, ne favor te rritjes se eficences dhe efektivitetit te bizneseve kosovare." Revista shkencore shoqerore ekonomike"Administrim biznesi" (Universiteti i Prishtines) 1 (January 2011): 2.

[14] Mangold, W. Glynn, and David J. Faulds. "Social Media: The New Hybrid Element of the Promotion Mix.” Business Horizons 52, no. 4 (July 2009): 357-365. doi:10.1016/j.bushor.2009.03.002.

[15] Kirtiş, A. Kazım, and Filiz Karahan. "To Be or Not to Be in Social Media Arena as the Most Cost-Efficient Marketing Strategy after the Global Recession." Procedia - Social and Behavioral Sciences 24 (2011): 260-268. doi:10.1016/j.sbspro.2011.09.083.

[16] Tang, Qian, Bin Gu, and Andrew B. Whinston. "Content Contribution for Revenue Sharing and Reputation in Social Media: A Dynamic Structural Model.” Journal of Management Information Systems 29, no. 2 (October 2012): 41-76. doi:10.2753/mis0742-1222290203.

[17] Wade, J. "The new wild west.” Risk Management 56, no. 8 (2009): 26-31.

[18] Huotari, Lauri, Pauliina Ulkuniemi, Saila Saraniemi, and Minna Mäläskä. "Analysis of Content Creation in Social Media by B2B Companies.” Edited by HeikkiKarjaluoto, PauliinaUlkuniemi. Journal of Business \& Industrial Marketing 30, no. 6 (July 6, 2015): 761-770. doi:10.1108/jbim-05-2013-0118.

[19] Nadda, Vipin K., Sumesh Singh Dadwal, and AzmatFirdous. "Social Media Marketing." Handbook of Research on Integrating Social Media into Strategic Marketing (2015): 359-379. doi:10.4018/978-1-4666-8353-2.ch021.

[21] Kenly, Amy, and Bill Poston. “Social Media and Product InnovationEarly Adopters Reaping Benefits amidst Challenge and Uncertainty”. (January, 2011).Avaliable online:https://viewpoints.kalypso.com/entry/social-media-and-productinnovation.(accessed on 20 December 2019).

[22] Drahošová, Martina, and Peter Balco. "The Analysis of Advantages and Disadvantages of Use of Social Media in European Union." The 7th International Symposium on Frontiers in Ambient and Mobile Systems; Procedia Computer Science 109 (2017): 1005-1009. doi:10.1016/j.procs.2017.05.446.

[23] Nadaraja, Rubathee, and Rashad Yazdanifard. "Social media marketing: advantages and disadvantages." Center of Southern New Hempshire University (2013): 1-10.

[24] Alves, Helena, Cristina Fernandes, and MárioRaposo. "Social Media Marketing: A Literature Review and Implications." Psychology \& Marketing 33, no. 12 (November 11, 2016): 1029-1038. doi:10.1002/mar.20936.

[25] Nwokah, Gladson, Elizabeth Ugoji, and Joyce Ofoegbu. "Product development and organizational performance." African Journal of Marketing and Management 1, no. 3 (2009): 89-101.

[26] Rautela, Sonica, Sarika Sharma, and Shreya Virani. "Influence of Customer Participation in New Product Development: The Moderating Role of Social Media.” International Journal of Productivity and Performance Management ahead-of-print, no. ahead-of-print (October 26, 2020). doi:10.1108/ijppm-05-2020-0241. 
[27] Seyyedamiri, Nader, and LadanTajrobehkar. "Social Content Marketing, Social Media and Product Development Process Effectiveness in High-Tech Companies." International Journal of Emerging Markets 16, no. 1 (August 23, 2019 ): 75-91. doi:10.1108/ijoem-06-2018-0323.

[28] Idota, Hiroki, Joji Nakaya, and Masatsugu Tsuji. "Why Consumers Commit Voluntarily to Collaborative Innovation with Firms by Using Social Media?: Case of Japanese consumers ." 30th European Conference of the International Telecommunications Society (ITS): "Towards a Connected and Automated Society", Finland, (2019).

[29] Zhan, Yuanzhu, Kim Hua Tan, Leanne Chung, Lujie Chen, and Xinjie Xing. "Leveraging Social Media in New Product Development: Organisational Learning Processes, Mechanisms and Evidence from China.” International Journal of Operations \& Production Management 40, no. 5 (May 4, 2020): 671-695. doi:10.1108/ijopm-04-2019-0318.

[30] Cheng, Colin C.J., and Dennis Krumwiede. "Enhancing the Performance of Supplier Involvement in New Product Development: The Enabling Roles of Social Media and Firm Capabilities." Supply Chain Management: An International Journal 23, no. 3 (May 14, 2018): 171-187. doi:10.1108/scm-07-2017-0230.

[31] KAS. Statistical Yearbook of the Republic of Kosovo. Pristina: Kosovo Agency of Statistics, 2019, 188.

[32] Elena, Cerchia Alina. "Social Media - A Strategy in Developing Customer Relationship Management." Procedia Economics and Finance 39 (2016): 785-790. doi:10.1016/s2212-5671(16)30266-0.

[33] Adam Enfroy; "5 Ways to Define and Reach Your Target Market on Social Media."Socialbakers, 2021. Available online: https://www.socialbakers.com/blog/5-ways-to-define-and-reach-your-target-market-on-social-media $\quad$ (accessed on 20 December 2020).

[34] Appel, Gil, Lauren Grewal, Rhonda Hadi, and Andrew T. Stephen. "The Future of Social Media in Marketing." Journal of the Academy of Marketing Science 48, no. 1 (October 12, 2019): 79-95. doi:10.1007/s11747-019-00695-1.

[35] Kumar, V., JeeWon Brianna Choi, and Mallik Greene. "Synergistic Effects of Social Media and Traditional Marketing on Brand Sales: Capturing the Time-Varying Effects.” Journal of the Academy of Marketing Science 45, no. 2 (June 14, 2016): 268-288. doi:10.1007/s11747-016-0484-7.

[36] Parveen, Farzana, Noor IsmawatiJaafar, and SulaimanAinin. "Social Media's Impact on Organizational Performance and Entrepreneurial Orientation in Organizations." Management Decision 54, no. 9 (October 17, 2016): 2208-2234. doi:10.1108/md-08-2015-0336.

[37] Oyewobi, LuqmanOyekunle, Olufemi Seth Olorunyomi, Richard AjayiJimoh, and James OlabodeBamideleRotimi. "Impact of Social Media Usage on Performance of Construction Businesses (CBs) in Abuja, Nigeria." Journal of Financial Management of Property and Construction ahead-of-print, no. ahead-of-print (January 18, 2021). doi:10.1108/jfmpc-05-2020-0042.

[38] Mahoney, Megan. "The Impact of Social Media on Business in 2021.". Available online: https://www.singlegrain.com/blogposts/impact-of-social-media-in-todays-business-world/(accessed on 27 March 2020).

[39] Newberry C.,Dawley S. “The 5 Most Important Social Media Trends to Watch for in 2021."Hootsuite, (2020). Available online: https://blog.hootsuite.com/social-media-trends/ (accessed on 30 February 2021). 